\title{
Analisis Promethee II Sebagai Pendukung Keputusan Pemilihan Media Sosial
}

\author{
http://dx.doi.org/10.28932/jutisi.v6i3.2956 \\ Saifulloh $\bowtie \# 1$

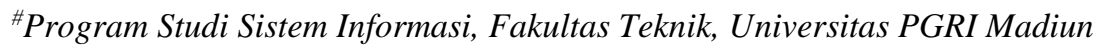 \\ Jl. Auri No. 14-16 Kota Madiun 63117 \\ ${ }^{1}$ saifulloheunipma.ac.id
}

\begin{abstract}
Nowadays, people cannot get away from social media. Social media is a part of the life of the wider community today, from teenagers to the elderly, many of which use social media to fill their spare time. Trends in the use of social media from various circles of society have many functions, such as news updates, online communication tools, sharing (data, images, and voice) without having to meet face to face. The impact of all social media use, this study aims to select the most popular social media used based on function, interest, or interface. This study uses the Promethee II method as an analysis of social media selection decisions with the results of calculations using Excel 2019. The alternative criteria objects in this study use popular social media such as Instagram, Whatsapp, Facebook, Line, and Telegram. The research method uses the stages of data collection, namely the survey method, distributing questionnaires to respondents to provide responses to the most popular social media assessors.
\end{abstract}

\section{Keywords - Promethee II; Social Media}

\section{Pendahuluan}

Saat ini orang tidak bisa lepas dari yang namanya media sosial. Media sosial menjadi bagian kehidupan masyarakat luas saat ini, mulai dari remaja hingga tua banyak yang bermain media sosial. Setiap hari rata-rata seseorang bisa bermain media sosial lebih dari 8 jam, bahkan media sosial dapat menjadi sumber penghasilan bagi seseorang. Media sosial menjadi sumber informasi baik tentang berita politik, informasi dan bahkan berita yang baru saja terjadi bisa langsung viral menyebar di media sosial [1]. Banyaknya informasi yang bisa dari media sosial itu sendiri, membuat banyak orang memanfaatkan untuk ajang promosi ataupun bisnis yang sedang mereka jalankan, untuk dipublikasikan ke media sosial. Dalam penggunaan media sosial jaman sekarang, piranti yang paling terpenting adalah internet. Teknologi informasi internet digunakan sebagai pengolahan data (input-analisis-proses-manipulasi) untuk menghasilkan feedback informasi yang berkualitas yang dapat diartikan informasi yang akurat, relevan untuk keperluan pribadi, bisnis, hingga government untuk pengambilan keputusan nantinya.
Banyaknya informasi dari segala media sosial, membuat seseorang bingung ingin menggunakan media sosial yang mana sesuai dengan banyaknya minat pengguna di media sosial tersebut. Sesuai dengan yang dimiliki para sahabat, relasi bisnis, maupun banyaknya pengguna yang dapat dijadikan teman dalam dunia maya. Selain mendapatkan informasi dari media sosial yang digunakan, seseorang juga bisa mengetahui aktivitas pengguna lain yang di publish di media sosial mereka, bahkan seseorang yang tidak dikenal pun kita dapat melihatnya melalui media sosial tersebut [2].

Dalam sistem pendukung keputusan pemilihan media sosial ini menggunakan metode Promethee II. Terdapat beberapa kriteria yang digunakan adalah Interface, Function dan Interest. Untuk menentukan media sosial yang sering digunakan para pengguna, maka penelitian ini memberikan beberapa pilihan media sosial seperti Instagram, Facebook, Line, Whatsapp dan Telegram. Dengan perhitungan Promethee II ini akan menentukan media sosial yang sering digunakan dan yang paling sesuai dengan minat para pengguna.

Berdasarkan penelitian sebelumnya, pada seminter IOP Conference Series : Materials Science and Engineering dengan judul "Application of MCMD using Promethee II Technique in the case of Social Media Selection for Online Businesses" dalam penggunaan Promethee II untuk merekomendasikan media sosial sebagai aplikasi penunjang bisnis online dengan menggunakan 300 responden sebagai data sampling penilaiannya seperti keamanan, fitur aplikasi, komunitas, kemudahan akses dan kecepatan respon sehingga menghasilkan perangkingan berdasarkan preferensi tertinggi yaitu Facebook dengan Net Flow tertinggi [3].

Kebermanfaatan penelitian ini adalah sebagai konsep logika matematika yang nantinya digunakan dalam pengembangan software DSS MCDM dan dapat dikembangkan secara teori dengan penambahan alternatif, kriteria serta nilai bobot untuk menghasilkan keputusan yang lebih akurat berdasarkan data multikriteria yang bervariasi. 


\section{KAJIAN PUSTAKA}

\section{A. Media Sosial}

Definisi media sosial berasal dari dua (2) kata yakni media dan sosial. Media berasal dari bahasa latin "Medium" yang berarti "perantara" artinya merupakan perantara sumber pesan (a source) dengan penerima pesan tersebut ( $a$ receiver) [1]. Menurut Durkheim, bahwa kata sosial "merujuk" pada kenyataan sosial (the social as social facts) bahwa setiap individu melakukan aksi yang memberikan kontribusi kepada masyarakat . Pernyataaan ini menegaskan bahwa pada kenyataannya media dan semua perangkat lunak (software) merupakan sosial dalam makna keduanya merupakan produk dari proses sosial" [2]. Berikut ini ada beberapa definisi dari media sosial antara lain yang dikemukakan oleh Mandibergh berpendapat bahwa "media sosial adalah media yang mewadahi kerjasama di antara pengguna yang menghasilkan konten (user generated content)" dimana barang orang dipertemukan dalam ruang virtual meskipun secara faktor geografis berjauhan. Kata media sosial sebagai convergency antara komunikasi personal untuk saling berbagi diantara individu (to be share one-to-one) dan media publik untuk berbagi kepada siapa saja tanpa ada kekhususan individu. Sehingga dapat diambil kesimpulan, dengan media sosial kita dapat melakukan bebagai aktifitas secara dua arah baik bertukar informasi, kolaborasi dan saling kenal dalam bentuk chat/tulisan, visual maupun audivisual [4].

Era milenial seperti sekarang banyak contoh media sosial yang popular berkembang seperti instagram, facebook, bigo, youtube, whatsapp dan sebagainya. Perbedaan teknologi informasi sangalah berkembang pesat, jaman dulu masih menggunakan media cetak dan broadcast dan berbeda pada era sekarang media sosial menggunakan internet (open feedback) dalam berbagi informasi serta respon secara online dalam waktu yang tepat situasi ini bisa disebut datangnya era baru yakni "Era Teknologi Digital" (new media) yang sifatnya kontemporer [5].

\section{B. Karakteristik Media Sosial}

Karakteristik media sosial tidak jauh beda dengan media siber (cyber), dikarenakan media sosial merupakan platform dari media siber [1]. Dengan demikian, suatu media sosial memiliki karakter khusus diantaranta :

1. Jaringan (network)

Merupakan infrastruktur yang menghubungkan antara computer dan hardware. Proses ini diperlukan karena nantinya komunikasi terjadi apabila computer terhubung dan melakukan perpindahan data

\section{Informasi (Informations)}

Entitas terpenting pada media sosisal dikarenakan digunakan untuk mengkreasikan representasi identitas, produksi konten dan interaksi informasi

3. Arsip (Archive)
Berfungsi untuk penyimpanan informasi dan dapat diakses kapanpun dan perangkat apapun juga

4. Interaksi (Interactivity)

Proses pembentukan jejaring diantara pengguna dan harus mempunyai interaksi antar pengguna

5. Simulasi Sosial (Simulasi of Society)

Media sosial memiliki karakter sebagai medium berlangsungnya masyarakat (society) di dunia virtual. Media sosial memiliki keunikan dan pola yang dalam banyak kasus berbeda dan tidak dijumpai dalam tatanan masyarakat yang real

6. Konten oleh pengguna (User generate Content)

Pada media sosial konten sepenuhnya milik dan berdasarkan kontribusi pengguna atau pemilik akun. UGC merupakan relasi simbiosis dalam budaya media baru yang memberikan kesempatan dan keleluasaan pengguna untuk berpartisipasi

\section{METODE PENELITIAN}

Metode penelitian pada studi kasus pemilihan media sosial menggunakan cara pengumpulan data dan pengolahan data. Adapun tahapan pengumpulan data dan pengolahan sebagai berikut :

\section{A. Metode Pengumpulan Data}

Metode pengumpulan data yang digunakan adalah data primer dimana data diperoleh secara langsung dengan mengamati objek penelitian yakni penggunaan media sosial diberbagai kalangan [5]. Data primer dalam penelitian ini menggunakan metode survey lapangan melalui pembagian kuesioner kepada responden. Langkah kedua, wawancara dengan melakukan tanya jawab secara langsung terhadap pengguna media sosial untuk memperoleh tanggapan berdasarkan kriteria penilaian yakni segi tampilan, minat dan kegunaan. Langkah Ketiga adalah studi Pustaka, kegiatan ini untuk mencari referensi data yang sifatnya teoritis dan berhubungan dengan penelitian yang dilakukan sehingga dengan mempelajari literatur, jurnal penelitian, bahan ajar dan sumber lainnya untuk memperkuat keilmuan pada penelitian yang dibahas.

Teknik pengumpulan data dilakukan dengan cara penyebaran kuesioner terhadap 50 orang berbagai kalangan dengan jenis klasifikasi responden dapat dilihat pada Tabel I. Sedangkan rekap tanggapan penyebaran angket kuesioner yang digunakan pada tahap wawancara untuk menilai media sosial berdasarkan kriteria dapat dilihat pada Tabel II. 
TABEL I

DATA KLASIFIKASI RESPONDEN

\begin{tabular}{|c|c|c|c|}
\hline \multicolumn{2}{|c|}{ Klasifikasi Responden } & Jumlah & Persentase \\
\hline \multirow{3}{*}{ Usia } & $<17 \mathrm{Th}$ & 8 & $16 \%$ \\
\hline & $17-30 \mathrm{Th}$ & 24 & $48 \%$ \\
\hline & $>30 \mathrm{Th}$ & 18 & $36 \%$ \\
\hline \multicolumn{3}{|r|}{ Total \% } & $100 \%$ \\
\hline \multirow{2}{*}{ Status } & Pelajar & 30 & $60 \%$ \\
\hline & Umum & 20 & $40 \%$ \\
\hline \multicolumn{3}{|r|}{ Total \% } & $100 \%$ \\
\hline
\end{tabular}

TABEL III

REKAP TANGGAPAN KUESIONER

\begin{tabular}{|c|c|c|c|}
\hline $\begin{array}{c}\text { Uraian } \\
\text { Pertanyaan }\end{array}$ & Jawaban & Frekuensi & Persentase \\
\hline $\begin{array}{l}\text { Media sosial } \\
\text { yang anda } \\
\text { gunakan! } \\
\text { (boleh lebih } \\
\text { dari satu) }\end{array}$ & $\begin{array}{c}\text { Facebook } \\
\text { Whatsapp } \\
\text { Instagram } \\
\quad \text { Line } \\
\text { Telegram } \\
\text { Lainnya }\end{array}$ & $\begin{array}{c}30 \\
50 \\
45 \\
20 \\
18 \\
9 \\
\end{array}$ & $\begin{array}{c}60 \% \\
100 \% \\
90 \% \\
40 \% \\
36 \% \\
18 \% \\
\end{array}$ \\
\hline $\begin{array}{c}\text { Apa Fungsi } \\
\text { penggunaan } \\
\text { media sosial } \\
\text { menurut anda? }\end{array}$ & $\begin{array}{c}\text { Komunikasi } \\
\text { Promosi }\end{array}$ & $\begin{array}{l}38 \\
12\end{array}$ & $\begin{array}{l}76 \% \\
24 \%\end{array}$ \\
\hline $\begin{array}{c}\text { Bagaimana } \\
\text { tampilan media } \\
\text { sosial menurut } \\
\text { anda? }\end{array}$ & $\begin{array}{c}\text { Menarik } \\
\text { biasa }\end{array}$ & $\begin{array}{l}18 \\
32\end{array}$ & $\begin{array}{l}36 \% \\
64 \%\end{array}$ \\
\hline $\begin{array}{c}\text { Apakah anda } \\
\text { termasuk tipe } \\
\text { yang memiliki } \\
\text { kecenderungan } \\
\text { mengikuti tren } \\
\text { dalam } \\
\text { penggunaan } \\
\text { media sosial? }\end{array}$ & $\begin{array}{c}\text { Iya } \\
\text { tidak }\end{array}$ & $\begin{array}{l}11 \\
39\end{array}$ & $\begin{array}{l}22 \% \\
78 \%\end{array}$ \\
\hline
\end{tabular}

Pada tabel II merupakan hasil rekap kuesioner yang berisi pertanyaan terkait kriteria penilaian yang meliputi interface, function dan interest. Dalam pemetaan nilai per kriteria terhadap alternatif nantinya akan dilakukan dalam bab Analisa dan pembahasan

\section{B. Pengolahan Data}

Promethee II adalah salah satu metode penentuan urutan atau prioritas dalam MCDM (Multi Criterion Decision Making) sehingga metode ini dikenal karena konsepnya yang efisien dan simpel. Dugaan dari dominasi kriteria yang digunakan dalam Promethee II adalah penggunaan nilai dalam hubungan outraking [6]. Penggunaan promethee adalah menentukan dan menghasilkan keputusan dari beberapa alternatif. Langkah perhitungan metode Promethree II sebagai berikut :

Promethee II membuat keputusan atas beberapa alternatif yang nantinya akan membandingkan antara satu alternatif dengan alternatif lainnya (head to head) yang mana alternatif adalah obyek yang akan diseleksi [3], [6]. Promethee II akan memulai perangkingan dengan melihat nilai leaving flow apakah merupakan nilai tertinggi dibandingkan nilai data lainnya dan nilai etering flow merupakan nilai terendah sehingga akan terjadi perangkingan terhadap data-data alternatif. Promethee II merupakan pengembangan dari Promethee dengan mempertimbangkan nilai net flow dalam proses perangkingan. Terdapat enam (6) jenis/preferensi dalam Promethee : 1) Usual Criterion : pembuatan preferensi mutlak untuk alernatif yang memiliki nilai lebih baik; 2) Quasi Criterion : penentuan nilai quasi (q) yang nantinya dijadkan acuan dalam pengambilan keputusan; 3) Linier Criterion : terlebih dahulu menentukan kecenderungan nilai preferensi (p) digunakan sebagai pengambilan keputusan; 4) Level Criterion : dalam proses pembuatan keputusan ada tiga (3) level keputusan yakni preferensi lemah, mutlak lebih baik dan lebih buruk; 5) Linear Area Criterion : mempertimbangkan kecenderungan peningkatan preferensi secara linier; 6) Gausion Criterion. Tahapan implementasi model ini terdapat 7 langkah yakni :

1. Melakukan Normalisasi

Tahapan normalisasi matrik keputusan dilakukan agar nilai-nilai yang memiliki skala berbeda memliki nilai baru dengan skala bobot sama minimal 0 (nol) dan maksimal 1 (satu). Normalisasi menggunakan rumus persamaan sebagai berikut [7]:

$\mathrm{R}_{\mathrm{ij}}=\left(\mathrm{X}_{\mathrm{ij}}-\operatorname{Min}\left(\mathrm{X}_{\mathrm{ij}}\right)\right) /\left(\operatorname{Max}\left(\mathrm{X}_{\mathrm{j}}\right)-\operatorname{Min}\left(\mathrm{X}_{\mathrm{j}}\right)\right)$

Dimana :

$\mathrm{R}_{\mathrm{ij}}=$ nilai $\mathrm{i}$ dalam kriteria $\mathrm{j}$ yang ternormalisasi

$\mathrm{X}_{\mathrm{ij}} \quad=$ nilai lama alternatif $\mathrm{i}$ dalam kriteria $\mathrm{j}$

$\operatorname{Min}\left(\mathrm{X}_{\mathrm{j}}\right)=$ nilai min dalam kriteria $\mathrm{j}$

$\operatorname{Max}\left(\mathrm{X}_{\mathrm{j}}\right)=$ nilai maks dalam kriteri $\mathrm{j}$

2. Melakukan perbedaan alternatif/berpasangan

3. Memilih dan menghitung fungsi preferensi

Menentukan dominasi kriteria. Dimana dalam menentukan decision maker harus menentukan bobot atau dominasi kriteria. Menghitung nilai preferensi dapat dilakukan dengan menggunakan persamaan sebagai berikut [8], [9]:

$H(d)\left\{\begin{array}{l}0 \text { jika d }=0 \\ 0 \text { jika d } \leq 0 \\ 1 \text { jika } \mathrm{d} \geq 0\end{array}\right.$

Keterangan :

$\mathrm{H}(\mathrm{d})=$ fungsi selisih kriteria antar alternatif

$\mathrm{d} \quad=$ selisih nilai kriteria $\{\mathrm{d}=\mathrm{f}(\mathrm{a})-\mathrm{f}(\mathrm{b})\}$ 
4. Perhitungan nilai indeks Preferensi

Nilai fungsi preferensi yang sebelumnya didapat dari persamaan (1), nantinya akan dihitung Kembali untuk mendapatkan indeks preferensi multikriteria (keseluruhan kriteria pada alternatif). Berikut persamaan yang digunakan :

$$
\varphi(a, b)=\sum_{n-1}^{n} P i(a, b): \forall a, b \in A
$$

5. Menentukan Leaving flow dan Entering flow

Menghitung Leaving flow, jumlah dari yang memiliki arah mendekat dari node a yang disebut juga karakter pengukuran outraking

$$
\phi^{+}(a)=\frac{1}{n-1} \sum_{n=k} \varphi(a, x)
$$

Menghitung Entering flow, jumlah dari yang memiliki arah menjauh dari node a (pengukuran outraking)

$$
\phi^{-}(a)=\frac{1}{n-1} \sum_{n=k} \varphi(a, x)
$$

6. Menentukan Net Flow, dengan menggunakan persamaan berikut :

$$
\phi(a)=\phi^{-}(a)-\phi^{-}(a)
$$

Dimana semakin besar nilai Entering Flow dan semakin kecil Leaving Flow maka alternatif memiliki kemungkinan terpilih semakin besar dan apabila memiliki nilai Net Flow lebih tinggi maka menempati satu urutan yang lebih baik.

\section{HASIL DAN PEMBAHASAN}

\section{A. Menentukan Alternatif}

Media sosial banyak berkembang pesat seiring dengan semakin canggihnya teknologi informasi modern. Di masa pandemi sekarang platform media sosial banyak digunakan untuk proses pembelajaran mulai jenjang terendah sampai tinggi dikarenakan tidak memungkinkan melakukan pembelajaran secara tatap muka secara langsung hal ini bertentangan himbauan untuk physical distancing dan stay at home. Kegunaan media sosial di berbagai kalangan sangat variatif seperti alat komunikasi jarak jauh, promosi usaha berbasis marketplace, gaming, sharing data dan sebagainya. Beberapa contoh alternatif platform media sosial berdasarkan trend pengguna ditunjukkan pada Tabel III.

TABEL IIII

ALTERNATIF KRITERIA

\begin{tabular}{|c|c|}
\hline Trend Medsos & Kode \\
\hline Instagram & $\mathrm{A}$ \\
\hline Whatsapp & $\mathrm{B}$ \\
\hline Facebook & $\mathrm{C}$ \\
\hline Line & $\mathrm{D}$ \\
\hline Telegram & $\mathrm{E}$ \\
\hline
\end{tabular}

\section{B. Menentukan Kriteria}

Kriteria yang digunakan untuk penilaian media sosial yakni interface, function, interest. Kriteria berikut nantinya digunakan oleh responden dalam menilai media sosial yang paling popular yang sering digunakan sesuai uraian kriteria berikut pada Table IV.

TABEL IV

DATA KRITERIA

\begin{tabular}{|c|c|c|c|}
\hline No & Uraian Kriteria & Bobot & Kode \\
\hline 1. & Interface & $20 \%$ & $\mathrm{f} 1$ \\
\hline 2. & Function & $40 \%$ & $\mathrm{f} 2$ \\
\hline 3. & Interest & $40 \%$ & $\mathrm{f} 3$ \\
\hline
\end{tabular}

\section{Implementasi Promethee II}

Dalam implementasinya analisis keputusan dengan metode Promethee II ini menggunakan Ms. Excel 2019, dimana perhitungan manual ini dipakai dalam pengembangan aplikasi DSS MCMD baik secara website, desktop, mobile app dan lain-lainnya [10], [11]. Pertama, pemetaaan data alternatif terhadap kriteria yang diperoleh dari tabel II yakni penyebaran angket survey (kuesioner) sehingga didapat penilaian terhadap masing-masing alternatif media sosial berdasarkan kriteria penilaian yang tersaji pada Tabel V.

TABEL V

DATA PENILAIAN RESPONDEN

\begin{tabular}{|c|c|c|c|c|c|c|}
\hline \multirow{2}{*}{ No } & \multirow{2}{*}{ Kriteria } & \multicolumn{5}{|c|}{ Nilai Alternatif } \\
\cline { 3 - 7 } & & A & B & C & D & E \\
\hline 1 & f1 & 4 & 3 & 2 & 3 & 3 \\
\hline 2 & f2 & 3 & 4 & 4 & 2 & 4 \\
\hline 3 & $\mathbf{f 3}$ & 4 & 4 & 4 & 3 & 3 \\
\hline \multicolumn{2}{|l}{ Jumlah Nilai } & $\mathbf{1 1}$ & $\mathbf{1 1}$ & $\mathbf{1 0}$ & $\mathbf{8}$ & $\mathbf{1 0}$ \\
\hline
\end{tabular}

Bobot tingkat kepentingan yang digunakan responden untuk memberikan nilai terhadap alternatif (media sosial) dapat dilihat pada Tabel VI.

TABEL VI

TINGKAT KEPENTINGAN

\begin{tabular}{|c|c|}
\hline Bobot & Keterangan \\
\hline 5 & Sangat Baik \\
\hline 4 & Baik \\
\hline 3 & Cukup \\
\hline 2 & Kurang \\
\hline 1 & Sangat Kurang \\
\hline
\end{tabular}

Setelah data mempunyai bobot, Langkah selanjutnya sebagai berikut :

1. Menghitung selisih nilai antar alternatif terhadap kriteria tertentu

Menghitung selisih nilai kriteria (d), dilakukan dengan cara membandingkan alternatif satu dengan lainnya atau nilai alternatif a dikurangi dengan nilai alternatif $\mathrm{b}$ selanjutnya dilakukan perhitungan nilai fungsi preferensi-nya $H(d)$ sesuai persamaan (1) [11]. tahapan pertama dapat dilihat pada Tabel VII. 
TABEL VII

BOBOT KRITERIA TIAP ALTERNATIF

\begin{tabular}{|c|c|c|c|c|c|}
\hline Alternatif & $\mathbf{A}$ & B & $\mathrm{C}$ & D & $\mathbf{E}$ \\
\hline \multirow{3}{*}{$\mathbf{A}$} & & $\mathrm{f} 1=1$ & $\mathrm{f} 1=1$ & $\mathrm{f} 1=1$ & $\mathrm{f} 1=1$ \\
\hline & & $\mathrm{f} 2=0$ & $\mathrm{f} 2=0$ & $f 2=1$ & $\mathrm{f} 2=0$ \\
\hline & & $\mathrm{f} 3=1$ & $\mathrm{f} 3=0$ & $\mathrm{f} 3=1$ & $\mathrm{f} 3=1$ \\
\hline \multirow{3}{*}{ B } & $\mathrm{f} 1=1$ & & $\mathrm{f} 1=1$ & $\mathrm{f} 1=0$ & $\mathrm{f} 1=0$ \\
\hline & $\mathrm{f} 2=0$ & & $\mathrm{f} 2=0$ & $f 2=1$ & $\mathrm{f} 2=0$ \\
\hline & $\mathrm{f} 3=1$ & & $\mathrm{f} 3=0$ & $\mathrm{f} 3=1$ & $\mathrm{f} 3=1$ \\
\hline \multirow{3}{*}{ C } & $\mathrm{f} 1=0$ & $\mathrm{f} 1=0$ & & $\mathrm{f} 1=0$ & $\mathrm{f} 1=0$ \\
\hline & $\mathrm{f} 2=1$ & $\mathrm{f} 2=0$ & & $\mathrm{f} 2=1$ & $\mathrm{f} 2=0$ \\
\hline & $\mathrm{f} 3=0$ & $\mathrm{f} 3=0$ & & $\mathrm{f} 3=1$ & $\mathrm{f} 3=1$ \\
\hline \multirow{3}{*}{ D } & $\mathrm{f} 1=0$ & $\mathrm{f} 1=0$ & $\mathrm{f} 1=1$ & & $\mathrm{f} 1=0$ \\
\hline & $\mathrm{f} 2=0$ & $\mathrm{f} 2=0$ & $\mathrm{f} 2=0$ & & $\mathrm{f} 2=1$ \\
\hline & $\mathrm{f} 3=0$ & $\mathrm{f} 3=0$ & $\mathrm{f} 3=0$ & & $\mathrm{f} 3=0$ \\
\hline \multirow{3}{*}{$\mathbf{E}$} & $\mathrm{f} 1=0$ & $\mathrm{f} 1=0$ & $\mathrm{f} 1=1$ & $\mathrm{f} 1=0$ & \\
\hline & $\mathrm{f} 2=1$ & $\mathrm{f} 2=0$ & $\mathrm{f} 2=0$ & $\mathrm{f} 2=1$ & \\
\hline & $\mathrm{f} 3=0$ & $\mathrm{f} 3=0$ & $\mathrm{f} 3=0$ & $\mathrm{f} 3=0$ & \\
\hline
\end{tabular}

2. Menghitung nilai indeks preferensi

Nilai indeks preferensi diperoleh dari rata bobot fungsi preferensi pada Tabel VIII dimana diihitung dengan cara nilai kriteria yang diperoleh pada Tabel VII masing-masing alternatif dibagi dengan jumlah kriteria dan hasilnya berupa nilai indeks preferensi alternatif. Pada Tabel VIII menunjukkan hasil indeks preferensi keseluruhan alternatif.

TABEL VIII

INDEKS PREFERENSI

\begin{tabular}{|c|c|c|c|c|c|}
\hline Alternatif & A & B & C & D & E \\
\hline A & & 0.6667 & 0.3333 & 1 & 0.6667 \\
\hline B & 0.3333 & & 0.3333 & 0.3333 & 0.3333 \\
\hline C & 0.3333 & 0 & & 0.6667 & 0.3333 \\
\hline D & 0 & 0 & 0.3333 & & 0.3333 \\
\hline E & 0.3333 & 0 & 0.3333 & 0.3333 & \\
\hline
\end{tabular}

3. Menghitung Leaving Flow

Data jumlah yang memiliki arah mendekat dari node a, berikut perhitungan leaving flow pemilihan media sosial dengan menggunakan persamaan (3).

$$
\text { A } \quad \begin{aligned}
\phi^{+}(a) & =\frac{1}{5-1}(0.6667+0.3333+1+0.6667) \\
& =0.25^{*} 2.6667 \\
\text { B } \quad \phi^{+}(a) & =\frac{1}{5-1} \\
& =(0.3333+0.3333+0.6667+0.3333) \\
& \\
& \\
\text { C } \quad \phi^{+}(a) & =\frac{1}{5-1}(0.33 * 1633+0+0.6667+0.3333)
\end{aligned}
$$

$$
=0.25 * 1.3333
$$$$
0.3333
$$

$$
\begin{aligned}
\phi^{+}(a) & =\frac{1}{5-1}(0+0+0.3333+0.3333) \\
& =0.25^{*} 0.6667 \\
\text { E } \quad \phi^{+}(a) & =\frac{1}{5-1}(0.3333+0+0.3333+0.3333) \\
& =0.25^{*} 1 \\
& =0.2500
\end{aligned}
$$

4. Menghitung Entering Flow

Perhitungan pada tahapan ini menggunakan persamaan (4) dimana jumlah dari data yang memiliki arah menjauh dari node a disebut outraking

$$
\begin{aligned}
& \text { A } \quad \phi^{-}(a)=\frac{1}{5-1}(0.3333+0.3333+0+0.3333) \\
& =0.25 * 1 \\
& =0.2500 \\
& \text { B } \phi^{-}(a)=\frac{1}{5-1}(0.6667+0+0+0) \\
& =0.25 * 0.6667 \\
& =0.1667 \\
& \text { C } \quad \phi^{-}(a)=\frac{1}{5-1}(0.3333+0.3333+0.3333+0.3333) \\
& =0.25 * 1.3333 \\
& \text { D } \quad \phi^{-}(a)=\frac{1}{5-1}(1+0.6667+0.6667+0.3333) \\
& =0.25 * 3 \\
& =0.6667 \\
& \text { E } \quad \phi^{-}(a)=\frac{1}{5-1}(0.6667+0.6667+0.6667+0.3333) \\
& =0.25 * 1.6667 \\
& =0.4167
\end{aligned}
$$

5. Menghitung Net Flow

Nilai pada net flow diperoleh dari pengurangan nilai Leaving Flow dengan nilai Entering Flow berdasarkan persamaan (5). Tahap Net Flow merupakan tahap akhir proses Promethee II dimana hasil dari Net Flow merupakan nilai perangkingan dapat dilihat pada Tabel IX.

$$
\begin{aligned}
\phi(a) & =(0.6667-0.2500) \\
& =0.42 \\
\phi(a) & =(0.4167-0.1667) \\
& =0.25 \\
\phi(a) & =(0.3333-0.3333) \\
& =0 \\
\phi(a) & =(0.1667-0.6667) \\
& =-0.50 \\
\phi(a) & =(0.2500-0.4167) \\
& =-0.17
\end{aligned}
$$


TABEL IX

RANGKING MEDIA SOSIAL

\begin{tabular}{|l|c|l|c|c|}
\hline Alternatif & $\begin{array}{c}\text { Leaving } \\
\text { Flow }\end{array}$ & $\begin{array}{c}\text { Entering } \\
\text { Flow }\end{array}$ & $\begin{array}{c}\text { Net } \\
\text { Flow }\end{array}$ & Rangking \\
\hline Instagram & 0.6667 & 0.2500 & 0.42 & 1 \\
\hline Whatsapp & 0.4167 & 0.1667 & 0.25 & 2 \\
\hline Facebook & 0.3333 & 0.3333 & 0 & 3 \\
\hline Line & 0.2500 & 0.4167 & -0.17 & 4 \\
\hline Telegram & 0.1667 & 0.6667 & -0.50 & 5 \\
\hline
\end{tabular}

\section{KESIMPULAN}

Berdasarkan penelitian diatas dapat dijelaskan bahwa metode Promethee II ini bisa diterapkan dalam sistem pendukung keputusan pemilihan media sosial bagi para pengguna media sosial yang popular saat ini. Hasil penelitian yang dilakukan dengan memberikan kuisioner kepada pengguna media sosial tersebut, maka diperoleh kriteria-kriteria dari segi Interface, Function dan Interest terhadap alternatif yang diberikan untuk pemilihan media sosial meliputi Instagram, Facebook, Line, Whatsapp dan Telegram. Dari perhitungan menggunakan metode Promethee II tersebut diperoleh hasil perangkingan media sosial yang paling sering digunakan media sosial Instagram dengan skor 0.42 dari jumlah 50 responden/pengguna berbagai kalangan.

\section{DAFTAR PUSTAKA}

[1] I. A. Ratnamulyani and B. I. Maksudi, "Peran Media Sosial Dalam Peningkatan Partisipasi Pemilih Pemula Dikalangan Pelajar Di Kabupaten Bogor," Sosiohumaniora, vol. 20, no. 2, pp. 154-161, 2018.
[2] A. Setiadi, "Pemanfaatan media sosial untuk efektifitas komunikasi," J. Hum., vol. 16, no. 2, pp. 1-7, 2016.

[3] I. G. Iwan Sudipa et al., "Application of MCDM using PROMETHEE II Technique in the Case of Social Media Selection for Online Businesses," IOP Conf. Ser. Mater. Sci. Eng., vol. 835, no. $1,2020$.

[4] W. Rahardjo, N. Qomariyah, I. Andriani, M. Hermita, and F. N. Zanah, "Adiksi Media Sosial pada Remaja Pengguna Instagram dan WhatsApp: Memahami Peran Need Fulfillment dan Social Media Engagement," J. Psikol. Sos., vol. 18, no. 1, pp. 5-16, 2020.

[5] Y. Silalahi, Mesran, T. Zebua, and Suginam, "Penerapan The Extended Promethee II ( EXPROM II ) Untuk Penentuan Produk Diskon," KOMIK (Konferensi Nas. Teknol. Inf. dan Komputer), vol. I, pp. 57-63, 2017.

[6] B. Damanik and S. S. Swono Sibagariang, "Penerapan Preference Ranking Organization Method For Enrichment Evaluation (Promethee) Dalam Evaluasi Kinerja Dosen (Studi Kasus: Univ. Sari Mutiara Indonesia)," KOMIK (Konferensi Nas. Teknol. Inf. dan Komputer), vol. 2, no. 1, pp. 174-180, 2018.

[7] S. Lubis, "Penentuan Mustahik Menggunakan Glob. Extrem. Program. (Studi Kasus Badan Amil Zakat dan Sedekah Dewan Kemakmuran Masjid Jakarta)," Seminar Nasional Industri dan Teknologi (SNIT), Politeknik Negeri Bengkalis, pp. 256-265, 2016.

[8] D. N. Batubara, D. R. Sitorus P, and A. P. Windarto, "Penerapan Metode PROMETHEE II Pada Pemilihan Situs Travel Berdasarkan Konsumen," J. Sisfokom (Sistem Inf. dan Komputer), vol. 8, no. 1, pp. 46-52, 2019.

[9] S Janti, "Analisis Validitas Dan Reliabilitas Dengan Skala Likert Terhadap Pengembangan Si/Ti Dalam Penentuan Pengambilan Keputusan Penerapan Strategic Planning Pada Industri Garmen," Prosiding Seminar Nasional Aplikasi Sains \& Teknologi (SNAST) 2014, Yogyakarta, 15 November 2014,pp. 211-216.

[10] S. R. Ningsih and A. P. Windarto, "Penerapan Metode Promethee II pada Dosen Penerima Hibah P2M Internal," InfoTekJar (Jurnal Nas. Inform. dan Teknol. Jaringan), vol. 3, no. 1, pp. 20-25, 2018.

[11] J. Sidhu and S. Singh, "Using the improved PROMETHEE for selection of trustworthy cloud database servers," Int. Arab J. Inf. Technol., vol. 16, no. 2, pp. 194-202, 2019. 